\title{
Disseminated Mycobacterium chimaera infection associated with heater-cooler units after aortic valve surgery without endocarditis
}

\author{
Tannaz Asadi, MD, ${ }^{\mathrm{a}}$ Katherine Mullin, MD, ${ }^{\mathrm{a}}$ Eric Roselli, MD, ${ }^{\mathrm{b}}$ Douglas Johnston, MD, \\ Carmela D. Tan, MD, ${ }^{\mathrm{c}}$ E. Rene Rodriguez, $\mathrm{MD},{ }^{\mathrm{c}}$ and Steven Gordon, $\mathrm{MD}^{\mathrm{a}}$
}

From the Departments of ${ }^{\mathrm{a}}$ Infectious Disease, ${ }^{\mathrm{b}}$ Thoracic and Cardiovascular Surgery, and ${ }^{\mathrm{c}}$ Pathology, Cleveland Clinic, Cleveland, Ohio.

Received for publication Sept 20, 2017; revisions received Nov 16, 2017; accepted for publication Dec 3, 2017; available ahead of print Jan 31, 2018.

Address for reprints: Steven Gordon, MD, Department of Infectious Disease, Cleveland Clinic, 9500 Euclid Ave, G-21, Cleveland, OH 44195 (E-mail: gordons@ @cf.org).

J Thorac Cardiovasc Surg 2018;155:2369-74

$0022-5223 / \$ 36.00$

Copyright (C) 2017 by The American Association for Thoracic Surgery

https://doi.org/10.1016/j.jtcvs.2017.12.049

Video clip is available online.

The Food and Drug Administration issued its first warning about heater-cooler-associated Mycobacterium chimaera infection risk after coronary bypass and other cardiovascular procedures in October 2015, following the release of several adverse event reports in connection with the device. $^{1,2}$ The US Centers for Disease Control and Prevention (CDC) subsequently issued a Health Alert Network advisory regarding the potential risk of $M$ chimaera infections after heart surgery, noting that at the time roughly $60 \%$ of the 250,000 heart bypass procedures performed each year in the United States involve use of the affected 3T Heater-Cooler systems (LivaNova, London, United Kingdom). ${ }^{3}$ Contamination of the heatercooler units with $M$ chimaera most likely occurred during production at the LivaNova factory (formerly Sorin Group Deutschland $\mathrm{GmBH}$ ), which was confirmed by a recent whole-genome sequencing study. ${ }^{4}$ Through a series of experiments, LivaNova heater-cooler devices were proven to have potentiated aerosolization of $M$ chimaera and subsequently contaminated the operative field, subsequently causing disseminated infection. ${ }^{5-17}$ It is estimated that at least 70 cases of infections with $M$ chimaera after cardiac surgery have occurred due to site-point contamination of the water within the circuitry of heater-cooler devices used for heat exchange in cardiopulmonary bypass machines. ${ }^{5}$

$M$ chimaera infections after open-chest surgery in the current outbreak have been primarily associated with infective endocarditis (IE), sternal wound infections, or vascular graft infections, in addition to associated extravascular manifestations. ${ }^{5,18,19}$ We report 2 cases of disseminated

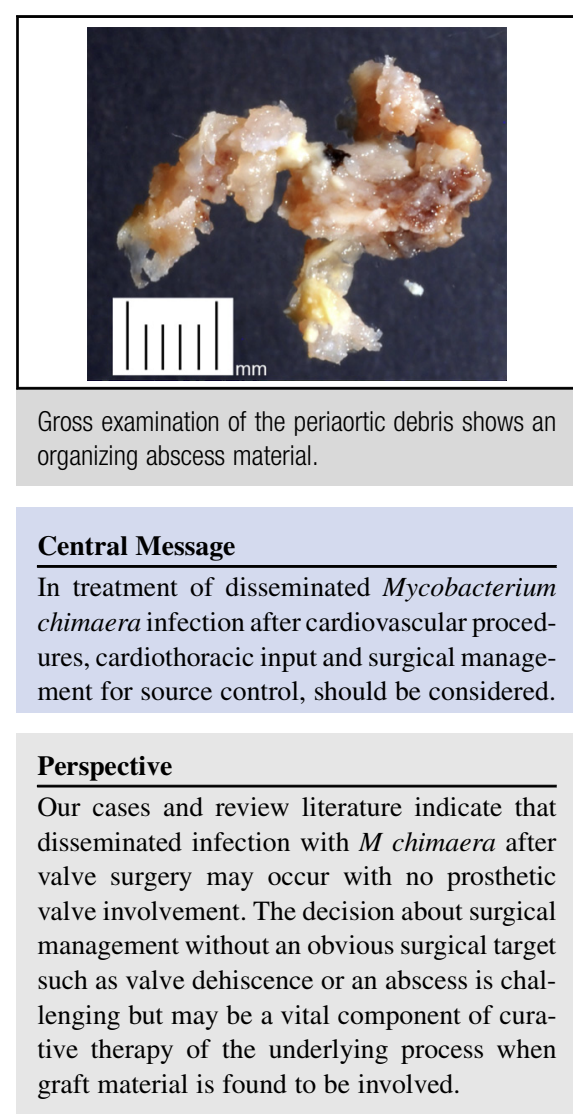

See Editorial Commentary page 2375.

$M$ chimaera infection, without IE, after valve-replacement surgeries associated with heater-cooler units and a subsequent review of the literature.

\section{CASE PRESENTATION}

\section{Case 1}

A 62-year-old man underwent an elective aortic root, ascending and arch replacement in June 2014 for an asymptomatic proximal aortic aneurysm. Valve pathology showed trileaflet aortic valve with dystrophic calcification. Sixteen months postoperatively, he developed night sweats, without fevers, and severe muscle aches in his proximal thighs with concomitant pain in his knees and hands. Evaluations showed mild anemia and elevated liver function tests, but there was no clear diagnosis, and he was treated 
symptomatically. In the interim, he continued to have involuntary weight loss and malaise.

Twenty-eight months postoperatively, blood cultures for mycobacteria were obtained after a family member close to the patient inquired regarding initial reports of Mycobacterial infections associated with heater-cooler units used in open-heart surgeries. The patient's blood cultures grew $M$ chimaera, which was subsequently isolated from specimens of urine and a liver biopsy (confirmed by National Jewish Health Laboratory, Denver, Colo). The pathology of the liver biopsy showed non-necrotizing granulomatous hepatitis. Ophthalmology examination demonstrated choroid lesions consistent with disseminated mycobacterial infection. A transesophageal echocardiography and positron emission tomography/computed tomography of the chest didn't show vegetation, abscess, or uptake. Despite the complaint of back pain, magnetic resonance imaging of the lumbar spine showed only degenerative changes at L4-L5.

The patient was treated with a combination of ethambutol, clofazimine, clarithromycin, and amikacin, with resolution of his night sweats and weight loss noted. Subsequent mycobacterial blood cultures were sterile, and lumbar back pain was his only persistent symptom. After 6 months of antimycobacterial treatment, the patient developed elevated creatinine $(2.2 \mathrm{mg} / \mathrm{dL})$ and bronzing of his skin (attributed to clofazimine). He was referred to our institution in May 2017 for a second opinion on further management. Repeat transesophageal echocardiography and positron emission tomography/computed tomography showed typical postoperative changes.

Because of concern of a persistent endovascular focus for the $M$ chimera infection, the patient underwent a redo median sternotomy with total aortic root, ascending, and arch replacement. The bioprosthetic valve appeared normal. Gross examination of the perigraft tissue showed no abscess (Figure 1), but pathologic examination demonstrated fibrofatty tissue with acute and chronic inflammation and multinucleated giant cells. A Fite-Faraco stain for mycobacteria was positive for acid-fast bacilli (Figure 2). Histologic evaluation of the bioprosthetic valve and explanted aortic graft revealed no evidence of inflammation. Polymerase chain reaction for Mycobacteria using hsp65 and rpoB primer sets for $M$ chimera was positive in the aortic perigraft specimen (confirmed by CDC). Mycobacterial cultures of the perigraft tissue, explanted valve, and graft material showed no growth.

Because of the patient's persistent back pain, repeat magnetic resonance imaging of the spine was completed and demonstrated L2-L3 vertebral osteomyelitis in addition to a left-sided psoas abscess. He subsequently underwent debridement of a thick-walled abscess in the left psoas muscle and L2-L3 disks and L2-L3 anterolateral interbody fusion with posterior percutaneous pedicle screw fixation. Cultures from the psoas abscess and bone grew $M$ chimera (susceptible to azithromycin, ethambutol, and rifampin).

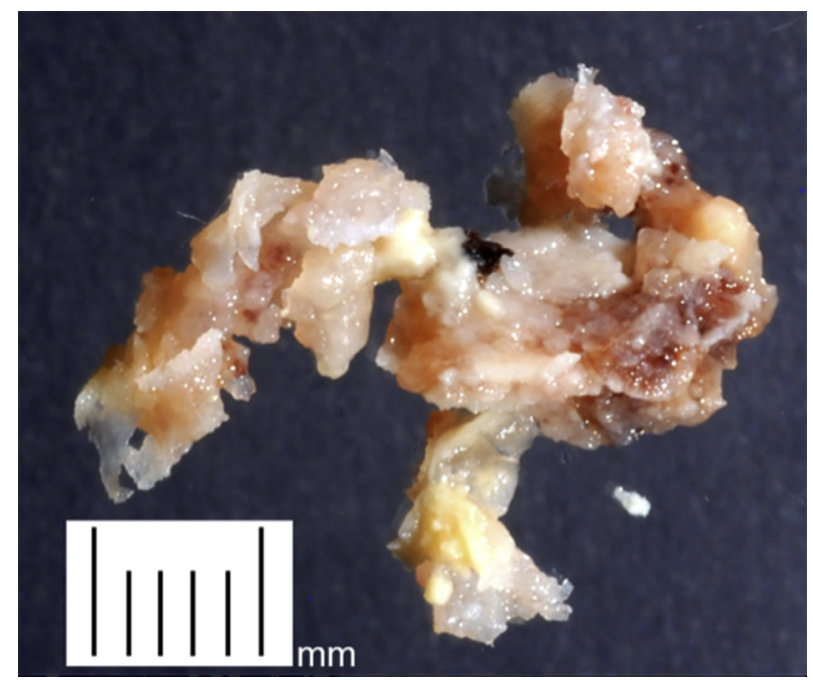

FIGURE 1. Gross examination of the periaortic debris shows yellow-totan tissue with some fibrous tissue strands (white tissue).

The patient was discharged home on a 4-drug antimycobacterial regimen of azithromycin, rifampin, ethambutol, and clofazimine with plans for at least 12 months of treatment. Four months after the heart surgery, he had clinically improved. His weight appropriately increased, he was tolerating the medications without significant side effects, and he has subsequently returned to work.

\section{Case 2}

Our second case was a 65-year-old man who was born with a bicuspid aortic valve that was originally replaced at an outside facility in 2004. In 2011, he underwent a repeat aortic valve replacement and aortic HEMASHIELD graft (MAQUET Holding B.V. \& Co KG, Rastatt, Germany) placement due to bioprosthetic valve stenosis. No underlying infection was suspected at the time of his surgery. Unfortunately, he never fully clinically recovered postoperatively, with notable fatigue, pancytopenia, and liver dysfunction noted. In 2014, he underwent aortic valve replacement for the third time and aortic graft replacement in the setting of early valve failure. Intraoperatively, he was found to have a large aortic pseudoaneurysm and aortic root abscess. The surgery was complicated by intraoperative innominate vein tear that required repair with Gore-Tex graft (W. L. Gore \& Associates, Inc, Flagstaff, Ariz). Mycobacterium avium intracellulare grew from valve tissue several weeks after the surgery and also in pleural fluid cultures aspirated a few days before the repeat surgery.

The patient was started on a regimen of ethambutol, rifampin, and azithromycin in July 2014. In the 12 months after his 2014 surgery, he experienced progressive systemic symptoms, including low-grade fevers, chills, and night sweats. Acid-fast bacilli staining from a subsequent bone 

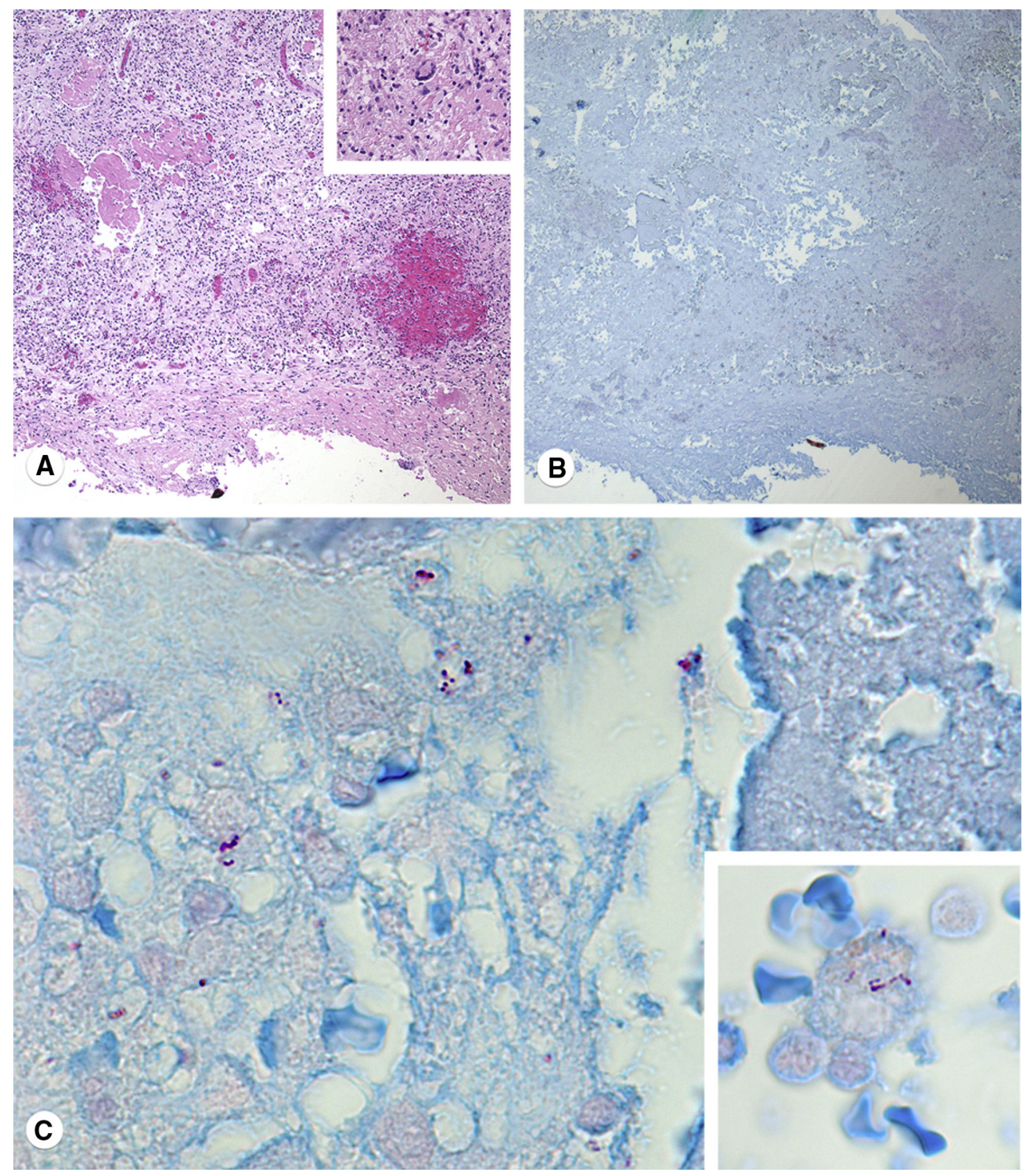

FIGURE 2. A, Light micrograph of the perigraft tissue shows abundant granulation tissue, rich in polymorphonuclear leukocytes undergoing karyorrhexis and conspicuous macrophages with foamy cytoplasm. Rare multinucleated giant cells were also present (inset). $\times 200$, hematoxylin and eosin. B, The same microscopic field shows no distinct mycobacteria at low magnification but many areas of foamy macrophages. $\times 200$, Fite-Faraco stain. C, Multiple mycobacterial organisms are seen within foamy macrophages on oil-immersion microscopy. The inset shows a "banding" pattern of stain of the mycobacteria. $\times 1000$, Fite-Faraco stain.

marrow biopsy, completed in the setting of worsening pancytopenia and abnormal liver function testing, was negative.

Despite antimicrobial therapy, the patient's cytopenia and liver dysfunction worsened, and he developed progressively severe hypercalcemia. He also had developed worsening, unexplained renal failure. Serial computed tomography scans revealed worsening of the aortic root abscess. In July 2015, the aortic root fluid collection was reaspirated by interventional radiology and cultures redemonstrated Mycobacterium avium intracellulare. He was then transferred to Cleveland Clinic for further management. At the time of transfer, transesophageal echocardiography was notable for an echolucency and thickening anterior to the replaced aortic root consistent with aortic root abscess. No definitive vegetations were seen on the prosthetic valve. Bone marrow biopsy was repeated and revealed noncaseating granulomas. Mycobacterium culture from bone marrow was negative. The patient was continued on rifampin, ethambutol, and azithromycin during his hospitalization.

$\mathrm{He}$ underwent chest exploration in late August 2015. There was a large abscess around the aortic graft. The abscess drained, and all foreign material around the graft was 
removed. A more aggressive procedure was considered but was felt to be injudicious due to his clinical fragility. Histologic examination of the perigraft aortic tissue showed fibrinous exudates with occasional acid-fast bacilli (Figure 3). $M$ avium-intracellulare complex was detected by DNA Gene Probe, which was later further specified as $M$ chimaera by using $16 \mathrm{~S}$ rRNA and rpoB gene sequencing in CDC. Per the patient's wishes, he returned to a facility closer to his home and passed away several months later.

\section{DISCUSSION}

As of August 2017, a total of 58 cases with disseminated $M$ chimaera infection associated with contaminated heatercooler units after open-heart surgery have been reported
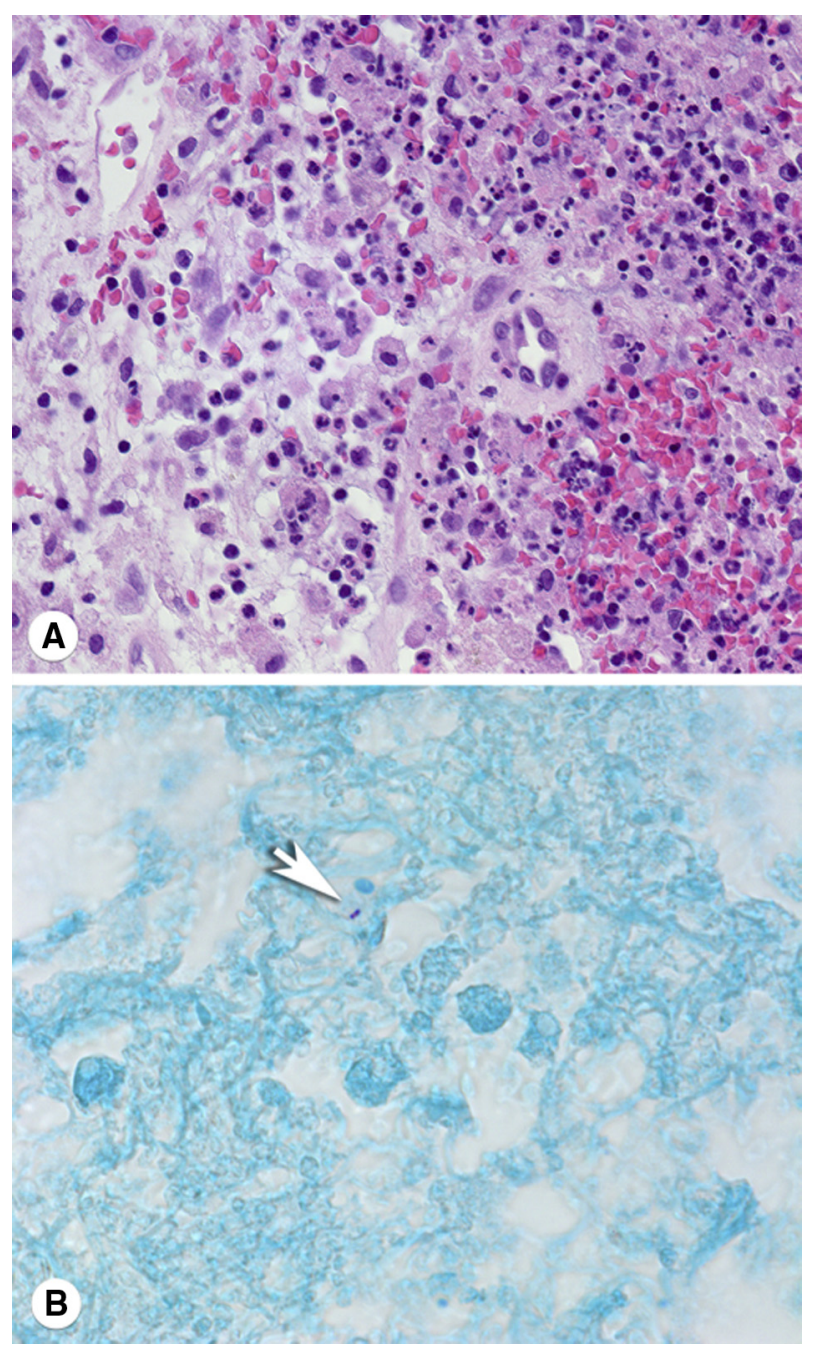

FIGURE 3. A, Similar to the first case, these images show abscess formation with karyorrhectic polymorphonuclear leukocytes at an interface with foamy macrophage inflammatory infiltrate. $\times 600$, hematoxylin and eosin. $\mathrm{B}$, Greater magnification shows a mycobacterium (arrow) inside a macrophage. $\times 1000$, Fite-Faraco stain. from Europe and the United States. ${ }^{2,16,18-23}$ Only 6 cases reported cardiac pathology: 4 cases had a definitive $M$ chimera IE as determined by examination of valve pathology; 1 case had granulomatous myocarditis; and 1 case reported granulomatous periaortic tissue with normal valves (Table 1).

Our first case confirms the observation that disseminated $M$ chimaera infections after cardiac surgery associated with heater-cooler units may occur without evidence of endovascular infection (valve or graft) despite the nidus of infection involving that prosthetic material. In the second case, there was no surgical histopathology sample, so we cannot say for certain that there was no valve or graft involvement, although imaging didn't demonstrate any endovascular infection findings. The perigraft surface is the area that is exposed to the operating room environment the longest during valvereplacement surgeries and may be the focus for initial infection with $M$ chimaera. There has been a noteworthy and ominous delay-to-diagnosis in these cases (average time of diagnosis is 1 month to 6 years), which has complicated the localization of initial source of infection and clinical outcomes. ${ }^{24}$ It is notable that the index case of disseminated $M$ chimaera related to the current outbreak, which occurred at a large cardiac center in Zurich, Switzerland, was detected only after the explanted valve was reviewed 3 years after the initial valve surgery was performed. ${ }^{2,5,16,25}$

From a mechanistic perspective, this delay to clinical disease and subsequent diagnosis has a theoretical immunologic explanation. Nontuberculosis mycobacteria, similar to Mycobacterium tuberculosis, use the macrophage as a natural tool of spread in the host. These micro-organisms manipulate the pattern of receptor recognition, production of cytokines, reactive oxygen and nitrogen species, phagosome maturation, and other killing mechanisms and can live inside macrophages even under immunological pressure. ${ }^{26}$ Histopathology of the explanted valve including inflammation, neovascularization, and demonstration of microorganisms remains the gold standard to establish diagnosis of IE; thus, pathologic examination can be especially valuable in cases of $M$ chimaera infection. ${ }^{27}$ Specimen triage of tissue samples for diagnostic studies also can be extremely valuable whenever there is uncertainty regarding the causative micro-organism, as molecular testing with polymerase chain reaction should be considered in this setting. However, our first case highlights the fact that the valve/graft may not always be involved. ${ }^{28-30}$

Delays in diagnosis and treatment in the setting of disseminated $M$ chimaera infection are multifactorial. We remain hopeful that earlier diagnosis and initiation of treatment will improve outcomes, as current evidence predicts high mortality after this diagnosis. Our current recommendations for early detection of IE after valve surgery are the following: 
TABLE 1. Microbiologic and histopathologic results of patients with $M$ chimaera infection who had cardiac pathology reports

\begin{tabular}{|c|c|c|c|c|c|c|c|c|}
\hline Study & $\begin{array}{c}\text { Clinical } \\
\text { diagnosis }\end{array}$ & Blood Cx & $\begin{array}{l}\text { Cardiac } \\
\text { tissue } \mathbf{C x}\end{array}$ & $\begin{array}{c}\text { Positive Cx } \\
\text { for } \\
\text { M chimaera } \\
\text { from } \\
\text { other sites }\end{array}$ & $\begin{array}{c}\text { Positive } \\
\text { cardiac } \\
\text { tissue PCR } \\
\text { for } M \\
\text { chimaera }\end{array}$ & $\begin{array}{c}\text { Cardiac tissue } \\
\text { pathology }\end{array}$ & $\begin{array}{c}\text { Involvement } \\
\text { of valves }\end{array}$ & $\begin{array}{c}\text { Other sites of } \\
\text { pathology }\end{array}$ \\
\hline $\begin{array}{l}\text { Kohler and } \\
\text { colleagues, } \\
2015^{19}\end{array}$ & IE & $M$ chimaera & $M$ chimaera & Sputum & Yes & $\begin{array}{l}\text { Necrotizing } \\
\text { endocarditis }\end{array}$ & Yes & \\
\hline $\begin{array}{l}\text { Kohler and } \\
\text { colleagues, } \\
2015^{19}\end{array}$ & Myocarditis & M chimaera & Not done & Sputum/urine & Not done & $\begin{array}{c}\text { Granulomatous } \\
\text { myocarditis }\end{array}$ & No & $\begin{array}{l}\text { Granulomatous nephritis } \\
\text { and hepatitis/ } \\
\text { granulomatous lesions } \\
\text { in brain and spleen }\end{array}$ \\
\hline $\begin{array}{l}\text { Kohler and } \\
\text { colleagues, } \\
2015^{19}\end{array}$ & IE & Negative & $M$ chimaera & Bone & Yes & $\begin{array}{c}\text { Granulomatous } \\
\text { endocarditis }\end{array}$ & Yes & $\begin{array}{r}\text { Granulomatous } \\
\text { osteomyelitis }\end{array}$ \\
\hline $\begin{array}{l}\text { Kohler and } \\
\text { colleagues, } \\
2015^{19}\end{array}$ & $\begin{array}{c}\text { Vascular graft } \\
\text { infection }\end{array}$ & Negative & $M$ chimaera & $\begin{array}{l}\text { Bone/sputum/ } \\
\text { urine }\end{array}$ & Yes & $\begin{array}{c}\text { Granulomatous } \\
\text { endocarditis }\end{array}$ & Yes & $\begin{array}{l}\text { Granulomatous } \\
\text { osteomyelitis/ } \\
\text { granulomatous } \\
\text { lesions in brain }\end{array}$ \\
\hline $\begin{array}{l}\text { Kohler and } \\
\text { colleagues, } \\
2015^{19}\end{array}$ & $\begin{array}{c}\text { Vascular graft } \\
\text { infection }\end{array}$ & M chimaera & $P$ acnes & Bone & Yes & $\begin{array}{l}\text { Granulomatous } \\
\text { periaortic tissue }\end{array}$ & No & $\begin{array}{c}\text { Granulomatous } \\
\text { nephritis }\end{array}$ \\
\hline $\begin{array}{l}\text { Kohler and } \\
\text { colleagues, } \\
2015^{19}\end{array}$ & IE & Not done & $M$ chimaera & & Yes & $\begin{array}{c}\text { Granulomatous } \\
\text { endocarditis }\end{array}$ & Yes & \\
\hline Current case 1 & $\begin{array}{l}\text { Perigraft tissue } \\
\text { infection and } \\
\text { Spondylodiscitis }\end{array}$ & $M$ chimaera & $M$ chimaera & $\begin{array}{l}\text { Urine/liver/ } \\
\text { psoas } \\
\text { abscess/ } \\
\text { perigraft } \\
\text { tissue }\end{array}$ & Yes & $\begin{array}{l}\text { Acute and chronic } \\
\text { inflammation, } \\
\text { positive AFB stain } \\
\text { in perigraft tissue }\end{array}$ & No & $\begin{array}{l}\text { Granulomatous } \\
\text { hepatitis } \\
\text { and nephritis/ } \\
\text { spondylitis (lumbar) } \\
\text { with psoas abscess }\end{array}$ \\
\hline Current case 2 & $\begin{array}{l}\text { Para-aortic tissue } \\
\text { infection }\end{array}$ & Negative & $M$ chimaera & $\begin{array}{l}\text { Pleural fluid/ } \\
\text { aortic } \\
\text { abscess }\end{array}$ & Yes & $\begin{array}{c}\text { Fibrinous exudates, } \\
\text { positive AFB in } \\
\text { para-aortic tissue }\end{array}$ & No & \\
\hline
\end{tabular}

$C x$, culture; $P C R$, polymerase chain reaction; $I E$, infective endocarditis; $A F B$, acid-fast bacilli.

1) All patients with prosthetic valves/rings should be educated that before receiving antimicrobial for febrile illness (empiric or otherwise); they should request blood cultures from their clinicians. ${ }^{24,27}$

2) Blood cultures should be held for at least 10 days to rule out infection with Propionibacterium acnes. This organism is a slow-growing, anaerobic, Gram-positive bacillus and a recognized cause of culture negative prosthetic valve endocarditis. $^{31}$

3) If blood cultures are negative and prosthetic valve endocarditis is still a consideration, then Mycobacterial blood cultures should be obtained. ${ }^{24}$

Disseminated $M$ chimaera infection may involve almost any organ system; therefore, there should be a low threshold for surgical evaluation of metastatic foci for source control. Treatment of $M$ chimaera infections should include a combination of antimicrobials based on susceptibilities and a macrolide-based regimen and addition of intravenous amikacin if possible. ${ }^{32}$

\section{CONCLUSIONS}

The role of surgery in the treatment of disseminated $M$ chimaera infections to remove infected valves/grafts and

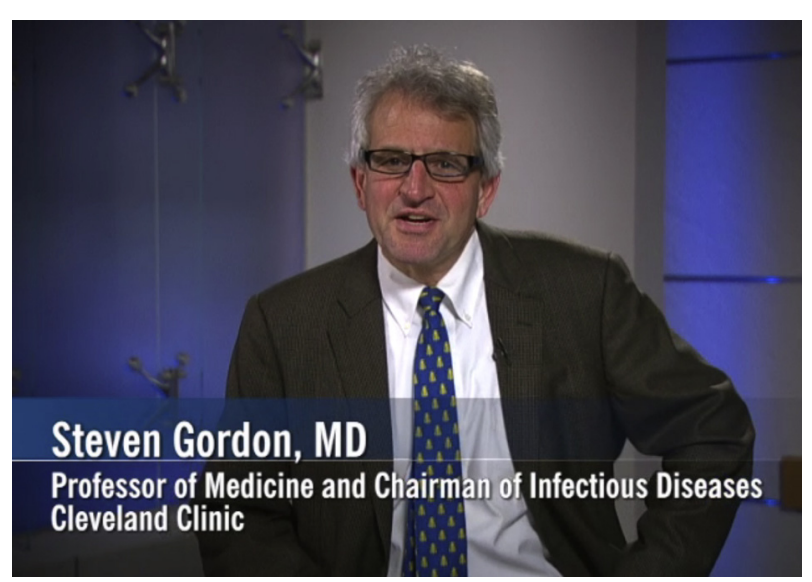

VIDEO 1. The challenges of disseminated $M$ chimaera infection associated with heater-cooler units after valve-replacement surgery. 
perigraft tissue should be considered, given the likelihood of involvement if index surgery used the associated heater-cooler units. Surgical management of extracardiac involvement in discreet organ systems should also be discussed by the multidisciplinary clinical team. Our report highlights that dissemination of $M$ chimaera infection may occur without evidence of valve or graft involvement. If there is no evidence of valve or graft infection on echo or other imaging, the decision about early complete explant is challenging; however, when there is a high suspicion of prosthetic material involvement, surgical excision may be imperative to eradicate the infection. For summary please watch the Video 1.

\section{Conflict of Interest Statement}

Authors have nothing to disclose with regard to commercial support. MD.

The authors thank Laraine L. Washer, MD, and Leal Herlitz,

\section{References}

1. Food and Drug Administration. Nontuberculous Mycobacterium (NTM) Infections Associated With Heater-Cooler Devices (HCD) During Cardiothoracic Surgery. Gaithersburg, Md: FDA Circulatory System Devices Panel of the Medical Devices Advisory Committee; 2016.

2. Sax H, Bloemberg G, Hasse B, Sommerstein R, Kohler P, Achermann Y, et al. Prolonged outbreak of Mycobacterium chimaera infection after open-chest heart surgery. Clin Infect Dis. 2015;61:67-75.

3. Perkins KM, Lawsin A, Hasan NA, Strong M, Halpin AL, Rodger RR, et al. Notes from the field: Mycobacterium chimaera contamination of heater-cooler devices used in cardiac surgery-United States. MMWR Morb Mortal Wkly Rep. 2016;65:1117-8.

4. van Ingen J, Kohl TA, Kranzer K, Hasse B, Keller PM, Katarzyna Szafrańska A, et al. Global outbreak of severe Mycobacterium chimaera disease after cardiac surgery: a molecular epidemiological study. Lancet Infect Dis. 2017;17:1033-41.

5. Sommerstein R, Schreiber PW, Diekema DJ, Edmond MB, Hasse B, Marschall J, et al. Mycobacterium chimaera outbreak associated with heater-cooler devices: piecing the puzzle together. Infect Control Hosp Epidemiol. 2017;38:103-8.

6. Robicsek F, Daugherty HK, Cook JW, Selle JG, Masters TN, O'Bar PR, et al. Mycobacterium fortuitum epidemics after open-heart surgery. J Thorac Cardiovasc Surg. 1978;75:91-6.

7. Szabo I, Sarkozi K. Mycobacterium chelonei endemy after heart surgery with fatal consequences. Am Rev Respir Dis. 1980;121:607.

8. Hoffman PC, Fraser DW, Robicsek F, O'Bar PR, Mauney CU. Two outbreaks of sternal wound infection due to organisms of the Mycobacterium fortuitum complex. J Infect Dis. 1981;143:533-42.

9. Kuritsky JN, Bullen MG, Broome CV, Silcox VA, Good RC, Wallace RJ. Sternal wound infections and endocarditis due to organisms of the Mycobacterium fortuitum complex. Ann Intern Med. 1983;98:938-9.

10. Yew WW, Wong PC, Woo HS, Yip CW, Chan CY, Cheng FB. Characterization of Mycobacterium fortuitum isolates from sternotomy wounds by antimicrobial susceptibilities, plasmid profiles, and ribosomal ribonucleic acid gene restriction patterns. Diagn Microbiol Infect Dis. 1993;17:111-7.

11. Strabelli TMV, Siciliano RF, Castelli JB, Demarchi LM, Leão SC, VianaNiero C, et al. Mycobacterium chelonae valve endocarditis resulting from contaminated biological prostheses. J Infect. 2010;60:467-73.

12. Vukovic D, Parezanovic V, Savic B, Dakic I, Laban-Nestorovic S, Ilic S, et al. Mycobacterium fortuitum endocarditis associated with cardiac surgery, Serbia. Emerg Infect Dis. 2013;19:517-9.

13. Nagpal A, Wentink JE, Berbari EF, Aronhalt KC, Wright AJ, Krageschmidt DA, et al. A cluster of Mycobacterium wolinskyi surgical site infections at an academic medical center. Infect Control Hosp Epidemiol. 2014;35:1169-75.
14. Tortoli E, Rindi L, Garcia MJ, Chiaradonna P, Dei R, Garzelli C, et al. Proposal to elevate the genetic variant MAC-A, included in the Mycobacterium avium complex, to species rank as Mycobacterium chimaera sp. nov. Int J Syst Evol Microbiol. 2004:54:1277-85.

15. Cohen-Bacrie S, David M, Stremler N, Dubus J-C, Rolain J-M, Drancourt M. Mycobacterium chimaera pulmonary infection complicating cystic fibrosis: a case report. J Med Case Rep. 2011;5:473.

16. Achermann Y, Rossle M, Hoffmann M, Deggim V, Kuster S, Zimmermann DR, et al. Prosthetic valve endocarditis and bloodstream infection due to Mycobacterium chimaera. J Clin Microbiol. 2013;51:1769-73.

17. Falkinham JO III. Mycobacterial aerosols and respiratory disease. Emerg Infect Dis. 2003;9:763-7.

18. Haller S, Holler C, Jacobshagen A, Hamouda O, Sin MA, Monnet DL, et al. Contamination during production of heater-cooler units by Mycobacterium chimaera potential cause for invasive cardiovascular infections: results of an outbreak investigation in Germany, April 2015 to February 2016. Euro Surveill. 2016;21:30215.

19. Kohler P, Kuster SP, Bloemberg G, Schulthess B, Frank M, Tanner FC, et al. Healthcare-associated prosthetic heart valve, aortic vascular graft, and disseminated Mycobacterium chimaera infections subsequent to open heart surgery. Eur Heart J. 2015;36:2745-53.

20. Tan N, Sampath R, Abu Saleh OM, Tweet MS, Jevremovic D, Alniemi S, et al. Disseminated Mycobacterium chimaera infection after cardiothoracic surgery. Open Forum Infect Dis. 2016;3: ofw131.

21. Appenheimer AB, Diekema DJ, Berriel-Cass D, Crook T, Daley CL, Dobbie D, et al. Mycobacterium chimaera outbreak response: experience from four US healthcare systems. Open Forum Infect Dis. 2016;3(suppl 1) (abstract 2392).

22. Chand M, Lamagni T, Kranzer K, Hedge J, Moore G, Parks S, et al. Insidious risk of severe Mycobacterium chimaera infection in cardiac surgery patients. Clin Infect Dis. 2017;64:335-42.

23. Cai Y, Landolfo K, Renew JR. Mycobacterium infection from a cardiopulmonary bypass heater-cooler unit in a patient with steroid-induced immunosuppression. Can J Anaesth. 2017;64:513-6.

24. Marra AR, Diekema DJ, Edmond MB. Mycobacterium chimaera infections associated with contaminated heater-cooler devices for cardiac surgery: outbreak management. Clin Infect Dis. 2017;65:669-74.

25. Bush LM, Paturi A, Chaparro-Rojas F, Perez MT. Mycobacterial prosthetic valve endocarditis. Curr Infect Dis Rep. 2010;12:257-65.

26. Awuh JA, Flo TH. Molecular basis of mycobacterial survival in macrophages. Cell Mol Life Sci. 2017;74:1625-48.

27. Kavousi M, Leening MJ, Nanchen D, Greenland P, Graham IM, Steyerberg EW, et al. Comparison of application of the ACC/AHA guidelines, Adult Treatment Panel III guidelines, and European Society of Cardiology guidelines for cardiovascular disease prevention in a European cohort. JAMA. 2014;311:1416-23.

28. Brandão TJ, Januario-da-Silva CA, Correia MG, Zappa M, Abrantes JA, Dantas AM, et al. Histopathology of valves in infective endocarditis, diagnostic criteria and treatment considerations. Infection. 2017;45:199-207.

29. Levine GN, Bates ER, Bittl JA, Brindis RG, Fihn SD, Fleisher LA, et al. 2016 ACC/AHA guideline focused update on duration of dual antiplatelet therapy in patients with coronary artery disease: a report of the american college of cardiology/american heart association task force on clinical practice guidelines: an update of the 2011 ACCF/AHA/SCAI guideline for percutaneous coronary intervention, $2011 \mathrm{ACCF} / \mathrm{AHA}$ guideline for coronary artery bypass graft surgery, $2012 \mathrm{ACC} / \mathrm{AHA} / \mathrm{ACP} / \mathrm{AATS} / \mathrm{PCNA} / \mathrm{SCAI} / \mathrm{STS}$ guideline for the diagnosis and management of patients with stable ischemic heart disease, 2013 ACCF/ AHA guideline for the management of st-elevation myocardial infarction, 2014 AHA/ACC guideline for the management of patients with nonst-elevation acute coronary syndromes, and 2014 ACC/AHA guideline on perioperative cardiovascular evaluation and management of patients undergoing noncardiac surgery. Circulation. 2016;134:123-e155.

30. AATS Surgical Treatment of Infective Endocarditis Consensus Guidelines Writing Committee Chairs, Pettersson GP, Coselli JS, Hussain ST, Griffin B, Blackstone EH, Gordon SM, et al. 2016 The American Association for Thoracic Surgery (AATS) consensus guidelines: surgical treatment of infective endocarditis: executive summary. J Thorac Cardiothorac Surg. 2017;153:1241-58.

31. Banzon JM, Rehm SJ, Gordon SM, Hussain ST, Pettersson GB, Shrestha NK Propionibacterium acnes endocarditis: a case series. Clin Microbiol Infect. 2017;23:396-9.

32. van Ingen J, Egelund EF, Levin A, Totten SE, Boeree MJ, Mouton JW, et al. The pharmacokinetics and pharmacodynamics of pulmonary Mycobacterium avium complex disease treatment. Am J Respir Crit Care Med. 2012;186:559-65. 